\title{
DNA damage and oxidative status in newly diagnosed, untreated, dipper and non-dipper hypertensive patients
}

\author{
Mustafa Gür ${ }^{1}$, Zafer Elbasan ${ }^{1}$, Durmuş Yıldıray Şahin ${ }^{1}$, Nermin Yıldız Koyunsever ${ }^{1}$, Taner Şeker ${ }^{1}$, \\ Betül Özaltun $^{1}$, Murat Çaylı ${ }^{1}$ and Abdurrahim Kocyigit ${ }^{2}$
}

DNA damage occurs more often in hypertensive patients than in non-hypertensive individuals. We sought to investigate lymphocyte DNA damage and total antioxidant status (TAS) levels in patients with dipper hypertension (DH) and non-dipper hypertension (NDH). Thirty-three patients with NDH (NDH group), 31 patients with DH (DH group) and 20 healthy volunteers (control group) were included in the study. Measurements from ambulatory blood pressure monitoring were obtained for all subjects. DNA damage was assessed in peripheral lymphocytes by comet assay, and plasma TAS levels were determined using an automated measurement method. The mean DNA damage value of the NDH group was higher than that of both the DH and control groups $(P=0.002$ and $P<0.001$, respectively). The mean DNA damage value of the DH group was higher than that of the control group $(P<0.001)$. The mean TAS level of the NDH group was lower than that of both the DH and control groups $(P=0.001$ and $P<0.001$, respectively), and the mean TAS level of the DH group was lower than that of the control group $(P<0.001)$. DNA damage was negatively associated with TAS level $(r=-0.692, P<0.001)$ and positively associated with high sensitive $c$-reactive protein level $(r=0.315, P=0.012)$. DNA damage increased in the NDH group compared with both the DH group and control group. This condition may be related to increased oxidative stress in the NDH group compared with the $\mathrm{DH}$ and control groups.

Hypertension Research (2013) 36, 166-171; doi:10.1038/hr.2012.156; published online 25 October 2012

Keywords: antioxidant; DNA; dipper; hsCRP

\section{INTRODUCTION}

The incidence of atherosclerotic cardiovascular disease is strongly related to the elevation of blood pressure (BP). ${ }^{1}$ In hypertensive patients, BP is characterized by rhythm alterations over $24 \mathrm{~h}$ periods. ${ }^{2}$ It has been shown that $24 \mathrm{~h}$ ambulatory BP monitoring (ABPM) is a better predictor of subsequent complications than spot measurements of $\mathrm{BP}^{3}$

$\mathrm{ABPM}$ has shown that $\mathrm{BP}$ is highest during the day and lowest at night in both normotensives and hypertensives. ${ }^{4}$ Mean BP values are $10-20 \%$ lower at night than in the day. This condition is called 'dipper' change. However, in some hypertensives, in contrast to this normal change, nighttime BP lowering does not occur or shows a decrease of $<10 \%$, which is called 'non-dipper' change. ${ }^{5}$ Endothelial dysfunction and target organ injury are more severe in non-dipper hypertensive $(\mathrm{NDH})$ patients than in dipper hypertensive $(\mathrm{DH})$ patients, and $\mathrm{NDH}$ itself is a risk factor for increased mortality. ${ }^{6-9}$

Increased oxidative stress is known to be involved in the pathogenesis of hypertension (HT) and cardiovascular disease. ${ }^{10-13}$ Oxidative stress occurs when the level of reactive oxygen species (ROS) exceeds the level of the antioxidant defense systems. ${ }^{13}$ Previous studies have shown that patients with essential HT have a decreased antioxidant capacity and increased amounts of ROS. ${ }^{14,15}$ The effects of ROS on vascular function and the development of HT have been investigated previously. ${ }^{10,11}$ Superoxide rapidly inactivates endothelium-derived nitric oxide. ${ }^{12,16,17}$ Thus, oxidative stress may account for endothelial dysfunction in patients with $\mathrm{HT}^{18}$

DNA damage frequently occurs in cells exposed to oxidative stress. Increased oxidative stress may initiate lipid peroxidation in cell membranes, damage membrane proteins or cause DNA fragmentation. ${ }^{19-21}$ DNA damage caused by ROS occurs more often in hypertensive patients than normotensive patients. ${ }^{22}$ The measurement of DNA damage in lymphocytes is a valuable marker of oxidative stress. ${ }^{21,23}$ In this study, we sought to investigate lymphocyte DNA damage in patients with $\mathrm{DH}$ and $\mathrm{NDH}$.

\section{METHODS}

Subjects

The overall study population consisted of 64 consecutive patients: 33 subjects with NDH (NDH group) and 31 patients with $\mathrm{DH}$ (DH group). Twenty

${ }^{1}$ Department of Cardiology, Adana Numune Education and Research Hospital, Adana, Turkey and 2Department of Clinical Biochemistry, School of Medicine, Harran University, Sanliurfa, Turkey

Correspondence: Dr M Gür, Department of Cardiology, Adana Numune Education and Research Hospital, Adana 01150, Turkey

E-mail: drmugur@yahoo.com

Received 19 April 2012; revised 22 July 2012; accepted 26 July 2012; published online 25 October 2012 
healthy volunteers were also included in the study as a control group. The study patients had newly diagnosed, untreated mild to moderate HT. The inclusion criteria were being 18-55 years of age and, for women, having a regular menstrual cycle. The control group had multiple BP measurements $<140 / 90 \mathrm{~mm} \mathrm{Hg}$ over the 1-month period and were in the same age and gender range as the hypertensive patients. These subjects were non-medical staff from our hospital or their relatives. For inclusion in the control group, subjects had to have no known coronary risk factors or cardiac symptoms and normal electrocardiographic and echocardiographic examinations.

Exclusion criteria included the presence of neoplastic disease, recent major surgical procedures, dyslipidemia, concomitant inflammatory diseases such as infections and autoimmune disorders, liver and kidney disease, extreme-dipper type HT, use of regular medication for any reason, alcohol use and smoking habit. Patients suffering from organic coronary artery disease, vasospastic angina, heart failure, idiopathic hypertrophic and dilated cardiomyopathy, secondary and malignant HT, serum creatinine $>1.5 \mathrm{mg} \mathrm{dl}^{-1}$ or with a history of diabetes were also excluded from participation in the study. Subjects had not previously taken antihypertensive therapy. Subjects using any vasoactive drug and having ST segment or T-wave changes specific for myocardial ischemia, Q waves or incidental left bundle branch block on ECG were excluded from the study.

The study was conducted according to the recommendations set forth by the Declaration of Helsinki on Biomedical Research Involving Human Subjects. The Institutional Ethics Committee approved the study protocol, and each participant provided written, informed consent.

\section{$\mathrm{BP}$ measurement and $\mathrm{ABPM}$}

BP was measured using a mercury sphygmomanometer in an office setting. Systolic BP (SBP) and diastolic BP (DBP) were taken. Noninvasive $24 \mathrm{~h} \mathrm{ABPM}$ was performed with a portable, compact digital recorder (Tracker NIBP2, Delmar Reynolds Ltd., Hertford, UK) and analyzed using customized analytical software (Delmar Reynolds Medical Inc., Model 2169, Hertford, UK). All subjects wore an ABPM device for a single $24 \mathrm{~h}$ period. The device was programmed to inflate and record BP at pre-specified intervals (every 15 min during daytime hours and every 30 min during nighttime hours), which provided $\sim 80 \mathrm{BP}$ recordings during the $24 \mathrm{~h}$ period. The display of the ABPM was inactivated so that viewing each $\mathrm{BP}$ reading did not distract the subjects. For the analysis of the data reports, reports generated from a session of ABPM contained BP recordings for the entire $24 \mathrm{~h}$, heart rate, mean arterial pressure and BP load, as well as summary statistics for the overall $24 \mathrm{~h}$, daytime and nighttime periods. When the readings exceeded at least $80 \%$ of the total readings programmed for the testing period, the recording was considered valid and satisfactory.

\section{Diagnosis of HT}

In each subject, BP was measured on at least three separate days after $15 \mathrm{~min}$ of sitting comfortably and was then averaged. Each subject then underwent $24 \mathrm{~h}$ ABPM. Individuals who had SBP $\geqslant 140 \mathrm{~mm} \mathrm{Hg}$ and/or a $\mathrm{DBP} \geqslant 90 \mathrm{~mm} \mathrm{Hg}$ in the office setting, and in ABPM, an average $24 \mathrm{~h} \mathrm{SBP}>130 \mathrm{~mm} \mathrm{Hg}$ and/or DBP $>80 \mathrm{~mm} \mathrm{Hg}$, an average daytime $\mathrm{SBP}>135 \mathrm{~mm} \mathrm{Hg}$ and/or DBP $>85 \mathrm{~mm} \mathrm{Hg}$ or an average nighttime SBP $>125 \mathrm{~mm} \mathrm{Hg}$ and/or DBP $>75 \mathrm{~mm} \mathrm{Hg}$ were diagnosed as hypertensive. ${ }^{24}$ In addition, the subjects who had a $<10 \%$ reduction in BP from the daytime to the nighttime period were defined as $\mathrm{NDH}$, and the subjects who had a $\mathrm{BP}$ reduction $\geqslant 10 \%$ from the daytime to the nighttime period were considered $\mathrm{DH} .{ }^{5}$

\section{Blood sampling protocol}

After the HT diagnosis based on ABPM, peripheral venous blood samples were taken into heparinized tubes from all subjects in a fasting state between 0700 and 0800 hours. One milliliter of blood was immediately pipetted into another tube to measure DNA damage. The remaining blood was centrifuged at 3000 r.p.m. for $10 \mathrm{~min}$ for plasma separation. Plasma samples were stored at $-80^{\circ} \mathrm{C}$ until the analysis of total antioxidant status (TAS), hsCRP, triglyceride, total cholesterol, low-density lipoprotein, high-density lipoprotein and fasting glucose. hsCRP levels were measured with an otoanalyser (Aeroset, Abbott,
Holliston, MN, USA) using a commercial spectrophotometric kit (Scil Diagnostics GmbH, Sunnyvale, CA, USA).

\section{DNA Damage determination by alkaline comet assay}

Lymphocyte isolation for the comet assay was performed using Histopaque 1077 (Sigma Chemical Co. Ltd., Seoul, Korea). One milliliter of heparinized blood was carefully layered over $1 \mathrm{ml}$ histopaque and centrifuged for $35 \mathrm{~min}$ at $500 \mathrm{~g}$ at $25^{\circ} \mathrm{C}$. The interface bands containing lymphocytes were washed with phosphate-buffered saline and then collected by $15 \mathrm{~min}$ centrifugation at $400 \mathrm{~g}$. The resulting pellets were re-suspended in phosphate-buffered saline to obtain 20000 cells in $10 \mu$ l. Membrane integrity was assessed by means of the trypan blue exclusion method.

The endogenous lymphocytes' DNA damage was analyzed by alkaline comet assay according to the procedures outlined by Singh et al., ${ }^{25}$ with minor modifications. Ten microliters of fresh lymphocyte cell suspension (around 20000 cells) was mixed with $80 \mu \mathrm{l}$ of $0.7 \%$ low-melting-point agarose (SigmaAldrich, St Louis, MO, USA) in phosphate-buffered saline at $37^{\circ} \mathrm{C}$. Subsequently, $80 \mu \mathrm{l}$ of this mixture was layered onto slides that had previously been coated with $1.0 \%$ hot $\left(60^{\circ} \mathrm{C}\right)$ normal-melting-point agarose and covered with a coverslip at $4{ }^{\circ} \mathrm{C}$ for at least $5 \mathrm{~min}$ to allow the agarose to solidify. After removing the coverslips, the slides were submerged in freshly prepared, cold $\left(4^{\circ} \mathrm{C}\right)$ lysing solution $(2.5 \mathrm{M} \mathrm{NaCl}, 100 \mathrm{~mm}$ EDTA-2Na; $10 \mathrm{~mm}$ Tris-HCl, pH 10-10.5; 1\% Triton X-100 and 10\% DMSO added just before use) for at least $1 \mathrm{~h}$. Slides were then immersed in freshly prepared, alkaline electrophoresis buffer $\left(0.3 \mathrm{moll}^{-1} \mathrm{NaOH}\right.$ and $1 \mathrm{mmoll}^{-1} \mathrm{Na}_{2}$ EDTA, $\left.\mathrm{pH}>13\right)$ at $4^{\circ} \mathrm{C}$ for unwinding $(40 \mathrm{~min})$ and then electrophoresed $(25 \mathrm{~V} / 300 \mathrm{~mA}$, $25 \mathrm{~min}$ ). All of the above steps were conducted under red light or without direct light to prevent additional DNA damage. After electrophoresis, the slides were stained with ethidium bromide $\left(2 \mu \mathrm{g} \mathrm{ml}^{-1}\right.$ in distilled $\mathrm{H}_{2} \mathrm{O} ; 70 \mu \mathrm{l}$ per slide), covered with a coverslip and analyzed using a fluorescence microscope (Nikon, Tokyo, Japan) equipped with a rhodamine filter, using the epiflurescence method. The images of 100 randomly chosen nuclei $(50$ cells from each of two replicate slides) were visually analyzed. Each image was classified according to the intensity of the fluorescence in the comet tail and was given a value of $0,1,2,3$ or 4 (from undamaged class 0 to maximally damaged class 4 ) (Figure 1) so that the total scores of the slide were between 0 and 400 arbitrary units. All procedures were completed by the same biochemistry staff, and DNA damage was detected by a single observer who was not aware of the subjects' diagnoses.

\section{Measurement of TAS}

TAS of serum was determined using an automated measurement method. ${ }^{26}$ In this method, hydroxyl radical is produced. In the assay, ferrous ion solution, which is present in reagent 1 , is mixed with hydrogen peroxide, which is present in reagent 2 . The sequentially produced radicals, such as the browncolored dianisidinyl radical cation produced by the hydroxyl radical, are also potent radicals. In this assay, the antioxidative effect of the sample against the potent free radical reactions is measured. The assay has excellent precision values, which are lower than $3 \%$. The results are expressed as mmol Trolox equivalents per 1 .

\section{Statistical analysis}

Results are presented as mean \pm s.d. or frequency expressed as a percent. Categorical variables were compared using the $\chi^{2}$-test. For continuous variables, differences between two groups were assessed using the unpaired $t$-test. Comparisons among multiple groups were performed by one-way analysis of variance test for continuous variables. Associations between other variables and lymphocyte DNA damage properties were assessed by the Pearson's correlation coefficient. A $P$-value $<0.05$ was considered statistically significant.

\section{RESULTS}

Demographic and clinical characteristics

The demographic and clinical characteristics of the groups are shown in Table 1. The SBP and DBP in the office setting were similar in 


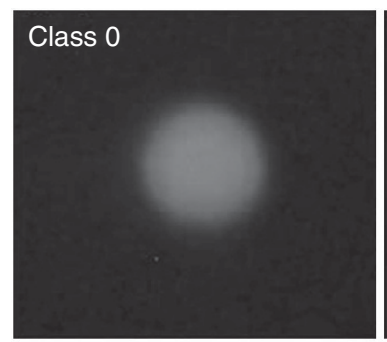

Class 3

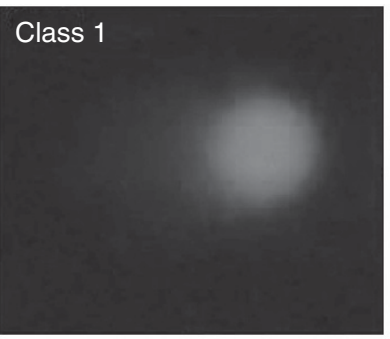

Class 2

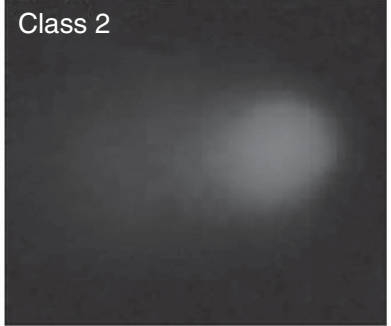

Class 4
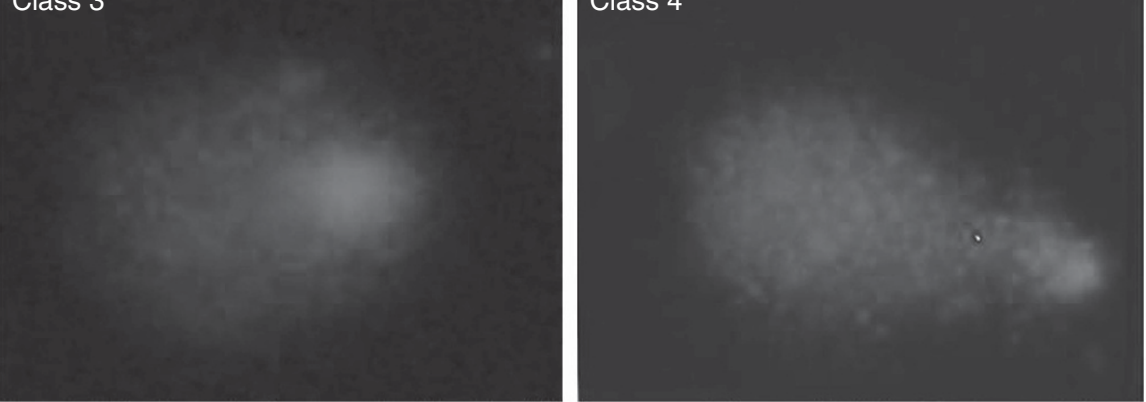

Figure 1 Photomicrographs showing varying intensities of fluorescence in the comet tail (class 0 , undamaged; class 4 and maximally damaged). A full color version of this figure is available at the Hypertension Research journal online.

Table 1 The comparison of baseline characteristic of the patient and control groups

\begin{tabular}{|c|c|c|c|c|}
\hline Variables & $\begin{array}{c}N D H \\
(\mathrm{n}=33)\end{array}$ & $\begin{array}{c}D H \\
(\mathrm{n}=31)\end{array}$ & $\begin{array}{l}\text { Control } \\
(\mathrm{n}=20)\end{array}$ & Anova P \\
\hline Age (years) & $48.6 \pm 6.1$ & $47.2 \pm 7.9$ & $49.6 \pm 3.5$ & 0.403 \\
\hline $\mathrm{BMI}\left(\mathrm{kg} \mathrm{m}^{-2}\right)$ & $26.6 \pm 2.6$ & $26.8 \pm 2.7$ & $26.2 \pm 3.5$ & 0.754 \\
\hline Male/female $(n / n)^{*}$ & $16 / 17$ & $14 / 17$ & $9 / 11$ & \\
\hline Office SBP (mm Hg) & $146.1 \pm 10.0$ & $145.1 \pm 10.6$ & $112.5 \pm 12.0 * *$ & $<0.001$ \\
\hline Office DBP (mm Hg) & $92.3 \pm 6.3$ & $91.3 \pm 8.5$ & $71.3 \pm 10.0^{* *}$ & $<0.001$ \\
\hline $\begin{array}{l}\text { Heart rate } \\
\text { (beats per min) }\end{array}$ & $76.9 \pm 11.5$ & $79.4 \pm 13.6$ & $77.7 \pm 11.9$ & 0.737 \\
\hline $\begin{array}{l}\text { Total cholesterol } \\
(\mathrm{mmol} \mathrm{I}-1)\end{array}$ & $4.98 \pm 0.75$ & $4.91 \pm 0.67$ & $4.80 \pm 0.50$ & 0.653 \\
\hline $\begin{array}{l}\text { LDL cholesterol } \\
\left(\mathrm{mmoll}^{-1}\right)\end{array}$ & $3.14 \pm 0.74$ & $3.15 \pm 0.68$ & $3.03 \pm 0.52$ & 0.806 \\
\hline $\begin{array}{l}\text { HDL cholesterol } \\
\left(\mathrm{mmoll}^{-1}\right)\end{array}$ & $1.12 \pm 0.16$ & $1.10 \pm 0.14$ & $1.10 \pm 0.09$ & 0.764 \\
\hline Triglyceride $\left(\mathrm{mmol} \mathrm{I}^{-1}\right)$ & $1.55 \pm 0.32$ & $1.46 \pm 0.25$ & $1.45 \pm 0.24$ & 0.302 \\
\hline $\begin{array}{l}\text { Fasting glucose } \\
\left(\mathrm{mg} \mathrm{dl}^{-1}\right)\end{array}$ & $97.5 \pm 10.0$ & $96.9 \pm 8.1$ & $95.3 \pm 6.2$ & 0.667 \\
\hline hscRP (mg dl-1) & $1.09 \pm 0.18$ & $0.95 \pm 0.18 * * *$ & $0.54 \pm 0.24 * *$ & $<0.001$ \\
\hline
\end{tabular}

Abbreviations: BMI, body mass index; DBP, diastolic blood pressure; DH, dipper hypertension; HDL, high-density lipoprotein; hscRP, high sensitive c-reactive protein; LDL, low-density lipoprotein; NDH, non-dipper hypertension; SBP, systolic blood pressure. * ${ }^{2}$-test; $P=0.955$.

$* * P<0.001$ vs. DH and NDH groups, ${ }^{* * *} P=0.008$ vs. NDH groups.

$\mathrm{DH}$ and NDH subjects. The SBP and DBP of both the DH and $\mathrm{NDH}$ groups in the office setting were higher than those of the control group.

\section{ABPM analysis}

The measurements from ABPM are shown in Table 2. By definition, the average daytime SBP and DBP did not differ between non-dippers and dippers. In contrast, the average nighttime SBP and DBP
Table 2 Data from ABPM of the dipping hypertension, non-dipping hypertension and control groups

\begin{tabular}{lcccc}
\hline & Non-dipper & Dipper & control & ANOVA P \\
\hline $\begin{array}{l}\text { Average 24h } \\
\text { systolic BP }\end{array}$ & $143.1 \pm 7.6^{*}$ & $134.9 \pm 4.7^{* *}$ & $108.9 \pm 4.0$ & $<0.001$ \\
$\begin{array}{l}\text { Average 24h } \\
\text { diastolic BP }\end{array}$ & $86.0 \pm 6.3$ & $84.8 \pm 5.8$ & $66.1 \pm 3.6 * * *$ & $<0.001$ \\
$\begin{array}{l}\text { Average daytime } \\
\text { systolic BP }\end{array}$ & $145.5 \pm 8.5$ & $144.6 \pm 5.8$ & $116.4 \pm 5.0 * * *$ & $<0.001$ \\
$\begin{array}{l}\text { Average daytime } \\
\text { diastolic BP }\end{array}$ & $88.2 \pm 6.7$ & $90.4 \pm 6.2$ & $72.4 \pm 5.6 * * *$ & $<0.001$ \\
$\begin{array}{l}\text { Average night-time } \\
\text { systolic BP }\end{array}$ & $140.8 \pm 7.5^{*}$ & $125.3 \pm 5.5^{* *}$ & $101.4 \pm 3.6$ & $<0.001$ \\
$\begin{array}{l}\text { Average night-time } \\
\text { diastolic BP }\end{array}$ & $84.0 \pm 6.1^{*}$ & $79.1 \pm 5.6^{* *}$ & $60.0 \pm 2.4$ & $<0.001$
\end{tabular}

Average night-ti diastolic BP

Abbreviations: ABPM, ambulatory blood pressure monitoring; ANOVA, analysis of variance; $\mathrm{BP}$, blood pressure.

${ }^{*} P<0.001$ vs. dipper and controls groups.

$* * P<0.001$ vs. control group.

$* * * P<0.001$ vs. dipper and non-dipper groups.

${ }^{\#} P<0.001$ vs. control group and $P=0.001$ vs. dipper group.

were significantly higher in the non-dipper HT group than in the dipper group or the control group.

\section{Analysis of antioxidant status and DNA damage}

The mean DNA damage values and hsCRP levels were higher in the $\mathrm{NDH}$ group than in the $\mathrm{DH}$ group or the control group. Additionally, the mean DNA damage value of the NDH group was higher than that of the DH group $(P<0.001)$. The mean TAS levels of both the DH and $\mathrm{NDH}$ groups were lower than that of the control group $(P<0.001$, for both). The mean TAS level of the NDH group was also lower than that of the DH group $(P<0.001)$. The analyses of antioxidant status and DNA damage are shown in Table 3.

\section{Correlation analysis}

In the patient groups, lymphocyte DNA damage was negatively correlated with TAS level $(r=-0.692, P<0.001)$, whereas lymphocyte DNA damage was positively correlated with age $(r=0.479$, 
Table 3 The comparison of antioxidant and DNA damage characteristic of the patient and control groups

\begin{tabular}{|c|c|c|c|c|}
\hline Variables & $\begin{array}{c}N D H \\
(\mathrm{n}=33)\end{array}$ & $\begin{array}{c}D H \\
(\mathrm{n}=31)\end{array}$ & $\begin{array}{l}\text { Control } \\
(n=20)\end{array}$ & ANOVA P \\
\hline $\begin{array}{l}\text { TAS (mmol Trolox } \\
\text { equiv per I) }\end{array}$ & $1.30 \pm 0.14$ & $1.42 \pm 0.11^{\oplus \oplus}$ & $1.62 \pm 0.11$ & $<0.001$ \\
\hline $\begin{array}{l}\text { Lymphocyte DNA } \\
\text { damage (AU) }\end{array}$ & $39.2 \pm 15.5^{\#}$ & $29.4 \pm 11.1^{\text {ตฯ }}$ & $9.0 \pm 4.5$ & $<0.001$ \\
\hline
\end{tabular}

Table 4 Bivariate relationships of the DNA damage values in patient group

\begin{tabular}{|c|c|c|}
\hline & Pearson's correlation coefficient & P-value \\
\hline Age & 0.479 & $<0.001$ \\
\hline Body mass index & 0.015 & 0.906 \\
\hline Gender (F/M) & 0.058 & 0.650 \\
\hline $\mathrm{SBP}(\mathrm{mm} \mathrm{Hg})$ & 0.063 & 0.620 \\
\hline $\mathrm{DBP}(\mathrm{mm} \mathrm{Hg})$ & 0.53 & 0.679 \\
\hline Fasting glucose & 0.142 & 0.262 \\
\hline Triglyceride $\left(\mathrm{mmoll}^{-1}\right)$ & 0.062 & 0.628 \\
\hline Total cholesterol $\left(\mathrm{mmol} \mathrm{I}^{-1}\right)$ & 0.382 & 0.002 \\
\hline LDL cholesterol $\left(\mathrm{mmol} \mathrm{I}^{-1}\right)$ & 0.331 & 0.008 \\
\hline HDL cholesterol (mmol per I) & 0.200 & 0.200 \\
\hline TAS (mmol Trolox Equiv per I) & -0.692 & $<0.001$ \\
\hline $\operatorname{hsCRP}\left(\mathrm{mg} \mathrm{dl}^{-1}\right)$ & 0.315 & 0.012 \\
\hline Heart rate (beats per min) & 0.055 & 0.676 \\
\hline Average $24 \mathrm{~h}$ systolic BP & 0.233 & 0.064 \\
\hline Average $24 \mathrm{~h}$ diastolic BP & 0.128 & 0.314 \\
\hline Average daytime systolic BP & 0.117 & 0.357 \\
\hline Average daytime diastolic BP & 0.010 & 0.938 \\
\hline Average night-time systolic BP & 0.260 & 0.038 \\
\hline Average night-time diastolic BP & 0.258 & 0.039 \\
\hline
\end{tabular}

Abbreviations: BP, blood pressure; DBP, diastolic blood pressure; HDL, high-density lipoprotein; hsCRP, high sensitive c-reactive protein; LDL, low-density lipoprotein; SBP, systolic blood pressure; TAS, total antioxidant status.

$P<0.001)$, hsCRP level $(r=0.315, P=0.012)$, total cholesterol level $(r=0.382, \quad P=0.002)$, low-density lipoprotein cholesterol level ( $r=0.331, P=0.008)$, average night-time SBP $(r=0.260, P=0.038)$ and average nighttime DBP $(r=0.258, P=0.039)$ in the bivariate analysis Table 4.

\section{DISCUSSION}

To the best of our knowledge, the present study is the first in to evaluate lymphocyte DNA damage and TAS in patients with DH and NDH. The main findings of this study are the following: ${ }^{1}$ the mean lymphocyte DNA damage and hsCRP levels of all patient groups were higher than those of the control group; ${ }^{2}$ the mean lymphocyte DNA damage and hsCRP levels were higher in the NDH group than the $\mathrm{DH}$ group ${ }^{3}$ the mean TAS levels of both the NDH and DH groups were lower than that of the control group; and the mean TAS levels of the NDH group were lower than those of the DH group; ${ }^{4}$ lymphocyte
DNA damage was negatively correlated with TAS and positively correlated with hsCRP.

Previous studies have shown that left ventricular hypertrophy, the risk of cardiovascular mortality, ${ }^{6,7}$ silent cerebrovascular disease ${ }^{8}$ and the progression of nephropathy ${ }^{9}$ are greater in subjects with nondipper BP than in patients with dipper $\mathrm{BP}^{6-9}$ At the same time, endothelium-dependent vasodilation induced by acetylcholine is impaired and the production of nitric oxide is reduced to a greater extent in non-dippers than in dippers. ${ }^{9}$

In the present study, lymphocyte DNA damage increased in hypertensive patients. This result is consistent with that of a previous study by Subash et al. ${ }^{22}$ They reported that increased DNA damage was related to a decreased TAS level. However, in that study, lymphocyte DNA damage was not investigated separately in patients with $\mathrm{NDH}$ and $\mathrm{DH}^{22}$ In our study, the extent of lymphocyte DNA damage was greater in the NDH group than in the DH group.

DNA damage frequently occurs in cells exposed to oxidative stress. Increased oxidative status may initiate lipid peroxidation in cell membranes, damage membrane proteins, or cause DNA fragmentation. ${ }^{27}$ Antioxidant systems prevent the damage of DNA. ${ }^{9}$ Honda et $a .^{28}$ have also reported that reduced activity of antioxidant enzymes is associated with increased levels of oxidative DNA damage. In the present study, lymphocyte DNA damage was significantly negatively correlated with TAS level. Thus, increased lymphocyte DNA damage in patients with NDH can be explained by decreased TAS levels, which are a marker of increased oxidative stress.

Lymphocyte DNA damage is one of the more reliable markers of oxidative stress. The most widely used techniques to investigate DNA damage are the comet assay and measurement of 7-hydroxy-8-oxo$2 \mathrm{~V}$-deoxyguanosine (8-oxodG). The comet assay detects singlestranded breaks in DNA. ${ }^{29,30}$ 8-oxodG can be measured by using several chromatographic techniques or non-chromatographic enzymic methods. There is a large variation in the measured levels of 8-oxodG between these assays, partly because 8 -oxodG is artificially generated in these assays, ${ }^{31}$ however, either approache can be used. ${ }^{30}$ In this study, to detect DNA damage in lymphocytes, we used the comet assay, which is a cheap, simple and very sensitive method. ${ }^{32}$

Maeda et al. ${ }^{33}$ demonstrated that oxidative stress generated by peripheral blood mononuclear cells was increased in hypertensives with an extreme-dipper pattern and/or a morning surge in BP. Recently, Ermis et al. ${ }^{34}$ investigated serum GGT levels, a marker of oxidative stress, and inflammatory activity in patients with $\mathrm{DH}$ and $\mathrm{NDH}$ and found that both serum GGT and CRP levels were increased in patients with NDH. They also reported that increased GGT activity was correlated with CRP levels. Yildiz et al. ${ }^{35}$ also showed increased signs of oxidative stress in patients with NDH compared with $\mathrm{DH}$. Decreased antioxidant levels have been interpreted as evidence of increased oxidative stress. Additionally, the plasma TAS level is an accurate index of oxidative stress, which provides a measure of the total plasma defenses against ROS. ${ }^{22,36}$ In the present study, we showed increased hsCRP levels and reduced TAS levels, a marker of increased oxidative stress, in the NDH group. It has been shown that increased pressure on vascular walls can induce ROS release and increase the level of oxidative stress. ${ }^{37-39}$ In the present study, the nocturnal SBP was higher in non-dippers than in dippers. Higher nocturnal BP may represent the primary mechanism of increased oxidative stress in patients with NDH. Thus, increased lymphocyte DNA damage in patients with NDH can be explained by increased oxidative stress. 


\section{Study limitations}

The comet assay is ideally suited for human investigations and can be easily applied. Normally, the lymphocytes that are used do not require tissue disaggregation, as they are obtained in a relatively noninvasive way, and they behave well in the comet assay. However, lymphocytes may not adequately reflect the damage to other organs in human subjects. ${ }^{32,40}$ Sometimes, human tissue removed at surgery can be investigated for elevated levels of damage; however, the necessary control tissue from healthy individuals is more difficult to obtain. In this study, we chose to use freshly isolated lymphocytes.

The lymphocyte DNA damage score in healthy control groups varies between 7.6 and 19.9 arbitrary units in the literature. ${ }^{41-43}$ This indicates that DNA damage evaluated by comet assay may vary depending on physicians and/or experimental conditions at measurement, such as $\mathrm{pH}$, duration of alkaline treatment, length of electrophoresis or types of cells used in single-cell gel electrophoresis. ${ }^{44}$ The optimization of experimental parameters for measuring lymphocyte DNA damage in the comet assay is necessary. In addition, there is no universally accepted cutoff value for the lymphocyte DNA damage score. To limit the variance, the lymphocyte DNA damage score can be confirmed by measuring 8-oxodG in patients with $\mathrm{DH}$ and NDH. However, the comet assay is a wellestablished, simple and sensitive method for measuring DNA damage and is commonly used in human trials. ${ }^{44}$ In this study, lymphocyte DNA damage was measured by alkaline comet assay, following the method of Singh et al. ${ }^{25}$

In conclusion, lymphocyte DNA damage increased in patients with $\mathrm{NDH}$ compared with patients with DH and the control group. The increased lymphocyte DNA damage, reduced TAS levels and increased hsCRP levels in patients with NDH might reflect increased oxidative stress and inflammatory activity, which have a crucial role in the development of cardiovascular disease. Lymphocyte DNA damage may be a parameter to consider in the treatment of HT.

\section{CONFLICT OF INTEREST}

The authors declare no conflict of interest.

1 Stokes 3rd J, Kannel WB, Wolf PA, D'Agostino RB, Cupples LA. Blood pressure as risk factor for cardiovascular disease. The Framingham Study -30 years of follow-up. Hypertension 1989; 13: 113-118.

2 O'Brien ET, Murphy J, Tyndall A, Atkins N, Mee F, McCarthy G, Staessen J, Cox J, O'Mally K. Twenty-four-hour ambulatory blood pressure in men and women aged 17 to 80 years: the Allied Irish Bank Study. J Hypertens 1991; 9: 355-360.

3 Staessen JA, Thijs L, Fagard R, O'Brien ET, Clement D, de Leeuw PW, Mancia G, Nachev C, Palatini P, Parati G, Tuomilehto J, Webster J. Predicting cardiovascular risk using conventional vs ambulatory blood pressure in older patients with systolic hypertension: systolic hypertension in Europe trial investigators. JAMA 1999; 282 539-546.

4 Mancia G, Ferrari A, Gregorini L, Parati G, Pomidossi G, Bertinieri G, Grassi G, di Rienzo M, Pedotti A, Zanchetti A. Blood pressure and heart rate variabilities in normotensive and hypertensive human beings. Circ Res 1983; 53: 96-104.

5 Verdecchia P, Schillaci G, Porcellati C. Dippers versus non-dippers. J Hypertens 1991; 9: 42-48.

6 Yamamoto Y, Akiguchi I, Oiwa K, Hayashi M, Kimura J. Adverse effect of nighttime blood pressure on the outcome of lacunar infarct patients. Stroke 1998; 29: 570-576.

7 Ohkubo T, Imai Y, Tsuji I, Nagai K, Watanabe N, Minami N, Kato J, Kikuchi N, Nishiyama A, Aihara A, Sekino M, Satoh H, Hisamichi S. Relation between nocturnal decline in blood pressure and mortality. The Ohasama Study. Am J Hypertens 1997; 10: 1201-1207.

8 Timio M, Venanzi S, Lolli S, Lippi G, Verdura C, Monarca C, Guerrini E. 'Non-dipper' hypertensive patients and progressive renal insufficiency: a 3-year longitudinal study. Clin Nephrol 1995; 43: 382-387.

9 Higashi Y, Nakagawa K, Kimura M, Noma K, Hara K, Sasaki S, Goto C, Oshima T, Chayama K, Yoshizumi M. Circadian variation of blood pressure and endothelial function in patients with essential hypertension:a comparison of dippers and non-dippers. J Am Coll Cardiol 2002; 40: 2039-2043.
10 Lassègue B, Griendling K. Reactive oxygen species in hypertension. An update Am J Hypertens 2004; 17: 852-860.

11 Touyz RM, Schiffrin EL. Reactive oxygen species in vascular biology: implications in hypertension. Histochem Cell Biol 2004; 122: 339-352.

12 Rodrigo R, Prat H, Passalacqua W, Araya J, Guichard C, Bächler JP. Relationship between oxidative stress and essential hypertension. Hypertens Res 2007; 30 : 1159-1167.

13 Park YK, Lee SH, Park E, Kim JS, Kang MH. Changes in antioxidant status, blood pressure, and lymphocyte DNA damage from grape juice supplementation. Ann NY Acad Sci 2009; 1171: 385-390.

14 Russo C, Olivieri O, Girelli D, Faccini G, Zenari ML, Lombardi S, Corrocher R. Antioxidant status and lipid peroxidation in patients with essential hypertension. J Hypertens 1998; 16: 1267-1271.

15 Prabha PS, Das UN, Koratkar R, Sagar PS, Ramesh G. Free radical generation, lipid peroxidation and essential fatty acids in uncontrolled essential hypertension. Prostaglandins Leukot Essent Fatty Acids 1990; 41: 27-33.

16 Dusting GJ, Akita K, Hickey H, Smith M, Gurevich V. Cyclosporin A and tacrolimus (FK506) suppress expression of inducible nitric oxide synthase in vitro by different mechanisms. Br J Pharmacol 1999; 128: 337-344.

17 Zicha J, Dobesova Z, Kunes J. Relative deficiency of nitric oxide-dependent vasodilation in salt-hypertensive Dahl rats: the possible role of superoxide anions. $J$ Hypertens 2001; 19: 247-254.

18 John S, Schmieder RE. Potential mechanisms of impaired endothelial function in arterial hypertension and hypercholesterolemia. Curr Hypertens Rep 2003; 5: 199-207.

19 Harangi M, Remenyik EE, Seres I, Varga Z, Katona E, Paragh G. Determination of DNA damage induced by oxidative stress in hyperlipidemic patients. Mutat Res 2002; 513 $17-25$

20 Halliwell B, Aruoma O. DNA damage by oxygen-derived species: its mechanism and measurement in mammalian systems. FEBS Lett 1991; 281: 9-19.

21 Gedik CM, Boyle SP, Wood SG, Vaughan NJ, Collins AR. Oxidative stress in humans: validation of biomarkers of DNA damage. Carcinogenesis 2002; 23 1441-1446.

22 Subash P, Premagurumurthy K, Sarasabharathi A, Cherian KM. Total antioxidant status and oxidative DNA damage in a South Indian population of essential hypertensives. J Hum Hypertens 2010; 24: 475-482.

23 Collins AR, Olmedilla B, Southon S, Granado F, Duthie SJ. Serum carotenoids and oxidative DNA damage in human lymphocytes. Carcinogenesis 1998; 19 2159-2162.

24 Stergiou GS, Salgami EV. World Health Organization-International Society of Hypertension (WHO-ISH); USA Joint National Committee on prevention, detection, evalutiaon, and treatment of high blood pressure (JNC-7); European Soceity of HypertensionEuropean Society of Cardiology (ESH-ESC). New European, American and International guidelines for hypertension management: agreement and disagreement. Expert Rev Cardiovasc Ther 2004; 2: 359-368.

25 Singh PN, McCoy MT, Tice RR, Schneider EL. A simple technique for quantitation of low levels of DNA damage in individual cells. Exp Cell Res 1988; 175: 184-191.

26 Erel O. A novel automated method to measure total antioxidant response against potent free radical reactions. Clin Biochem 2004; 37: 112-119.

27 Chen LY, Nichols WW, Hendricks J, Mehta JL. Myocardial neutrophil infiltration, lipid peroxidation, and antioxidant activity after coronary artery thrombosis and thrombolysis. Am Heart J 1995; 129: 211-218.

28 Honda M, Yamada Y, Tomonaga M, Ichinose H, Kamihira S. Correlation of urinary 8-hydroxy-2-de-oxyguanosine (8-OHdG), a biomarker of oxidative DNA damage, and clinical features of hematological disorders: a pilot study. Leuk Res 2000; 24 461-468.

29 Collins AR, Dusinska M, Gedik CM, Stetina R. Oxidative damage to DNA: do we have a reliable biomarker? Environ Health Perspect 1996; 4: 465-469.

30 Gedik CM, Wood SG, Collins AR. Measuring oxidative damage to DNA; HPLC and the comet assay compared. Free Radic Res 1998; 29: 609-615.

31 Møller P, Loft S. Oxidative DNA damage in human white blood cells in dietary antioxidant intervention studies. Am J Clin Nutr 2002; 76: 303-310.

32 Collins AR. The comet assay for DNA damage and repair: principles, applications, and limitations. Mol Biotechnol 2004; 26: 249-261.

33 Maeda K, Yasunari K, Watanabe T, Nakamura M. Oxidative stress by peripheral blood mononuclear cells is increased in hypertensives with an extreme-dipper pattern and/o morning surge in blood pressure. Hypertens Res 2005; 28: 755-761.

34 Ermis N, Yagmur J, Acikgoz N, Cansel M, Cuglan B, Pekdemir H, Ozdemir R. Serum gamma-glutamyl transferase (GGT) levels and inflammatory activity in patients with non-dipper hypertension. Clin Exp Hypertens 2012; 34: 311-315.

35 Yildiz A, Gur M, Demirbag R, Yilmaz R, Akyol S, Aslan M, Erel O. Paraoxonase and arylesterase activities in untreated dipper and non-dipper hypertensive patients. Clin Biochem 2008; 41: 779-784.

36 Dounousi E, Papavasiliou E, Makedou A, Ioannou K, Katopodis KP, Tselepis A, Siamopoulos KC, Tsakiris D. Oxidative stress is progressively enhanced with advancing stages of CKD. Am J Kidney Dis 2006; 48: 752-760.

37 Alexander RW. Theodore Cooper Memorial Lecture. Hypertension and the pathogenesis of atherosclerosis. Oxidative stress and the mediation of arterial inflammatory response: a new perspective. Hypertension 1995; 25 $155-161$

38 Landmesser U, Harrison DG. Oxidative stress and vascular damage in hypertension. Coron Artery Dis 2001; 12: 455-461. 
39 Kario K. Vascular damage in exaggerated morning surge in blood pressure. Hypertension 2007; 49: 771-772.

40 Müller WU, Bauch T, Stüben G, Sack H, Streffer C. Radiation sensitivity of lymphocytes from healthy individuals and cancer patients as measured by the comet assay. Radiat Environ Biophys 2001; 140: 83-89.

41 Altindag O, Karakoc M, Kocyigit A, Celik H, Soran N. Increased DNA damage and oxidative stress in patients with rheumatoid arthritis. Clin Biochem 2007; 40 $167-171$.
42 Baysal Z, Cengiz M, Ozgonul A, Cakir M, Celik H, Kocyigit A. Oxidative status and DNA damage in operating room personnel. Clin Biochem 2009; 42: 189-193.

43 Gur M, Yildiz A, Demirbag R, Yilmaz R, Koçyigit A, Celik H, Aksoy N. Increased lymphocyte deoxyribonucleic acid damage in patients with cardiac syndrome X. Mutat Res 2007; 617: 8-15.

44 Szeto $\mathrm{Y}$, Lee A, Benzie I, Obied H. Optimized noninvasive procedures to measure DNA damage in comet assay. Hum Exp Toxicol (e-pub ahead of print 31 May 2012; doi: 10.1177/0960327112446816). 